\title{
Epithelioid Malignant Peripheral Nerve Sheath Tumor
}

National Cancer Institute

\section{Source}

National Cancer Institute. Epithelioid Malignant Peripheral Nerve Sheath Tumor. NCI

Thesaurus. Code C6561.

A rare variant of malignant peripheral nerve sheath tumor composed predominantly or exclusively of epithelioid cells. 